\title{
THE FOREST AND ITS EFFECT ON STREAM-FLOW
}

\author{
By F. S. Newman, B.Sc.F.
}

\author{
Ontario Forestry Branch, St. Williams, Ontario
}

$\mathrm{F}^{\mathrm{n}}$

ROM the utilitarian viewpoint it is a matter of common knowledge that

"Forest Products" rank among the leading natural resources of this country. Moreover, the æsthetic value of tree growth is universally conceded. Beyond these two conceptions the average person fails to realize that the forest exerts invisible influences that are of infinite significance.

Of all the direct influences of the forest, that influence upon the supply of water in streams and upon the regularity of their flow is of greatest importance in human economy.

As the natural sequence of years of lumbering, our watersheds and head waters of large and small streams alike have become denuded, with the result that to-day we are faced with a serious problem demanding an intensive study and search for data of scientific accuracy with relation to the effect forests have on water flow.

\section{Forests AND PRecipitation}

Stream flow depends upon precipitation, and any factor instrumental in increasing precipitation is fundamental in determining the amount of water which ultimately finds its way to a stream or river.

Observations upon the influence of forests on local precipitation began as early as the middle of the last century, and these studies demonstrated beyond doubt that the amount of precipitation over forested areas was greater than that over open country.

One reason for this is unquestionably the tendency of moisture laden currents to precipitate more readily near the forest than over bare or cultivated fields at the same elevation, due to the dampening or chilling effect of the forest upon the atmosphere which induces a greater condensation of the water vapor.

The mechanical action of the forest is especially important in the case of snow. During heavy storms, forests not only catch more snow than do large open fields from which it is blown away, but they prevent it drifting, and bring about an even distribution.

Precipitation which reaches the ground and becomes available for vegetation and stream flow, comes from two chief sources. First, rain, snow, hail and sleet which form in the upper air strata. And secondly, dew, hoar-frost and like condensations which form on the surfaces of foliage, branches and trunks and even on the surface and in the interior of the soil when these are colder than the surrounding air. 


\section{Forests as Conservers of Precipitation}

All of the water that is precipitated over an area covered with vegetation does not go to swell the underground drainage which feeds the springs and the regular flow of streams. A part is intercepted by the branches of trees, or leaves of vegetation, and is evaporated from them, back into the air; another part evaporates from the soil; a third part runs off from the surface of slopes into the valleys below; another portion is absorbed by vegetation and used by it for the building up of tissue and transpiration; finally, the surplus filters through into the ground and goes to supply the streams.

The amount of water lost to stream flow on account of interception by vegetation, is much greater in the case of forests than on bare ground or meadow, and the question naturally arises, how then and in what way, does the forest function in making available a larger percentage of water for the streams?

In the case of rainfall, the amount of water which filters into the ground, depends, for one thing, upon the length of time the water remains in contact with the soil. The forest modifies both the severity and the duration of rainfall. By its foliage and branches it breaks the force of the rain so that the water reaches the soil without violence, and at the same time prolongs its duration. After a storm water continues to drop from the foliage, and has, therefore, a longer time and a better chance to be absorbed by the soil.

The rapid melting of the snow in the Spring, especially when the ground is frozen, or is saturated with water, forms surface run-off, and lessens seep. age. In cultivated fields and clearings the ground is naturally frozen when the snow melts. This, together with the rapid thawing in the open, causes the water, even on gentle slopes, to run off in gushing quantities before an appreciable seepage can take place. Open areas invariably freeze deeply due, chiefly, to unimpeded radiation during the Fall and to the blowing off during winter of the protective snow blanket.

In the forest, on the other hand, the soil is warmer than in the open. It is protected from radiation by the overhead tree growth. It is also protected by the leaf-litter-a poor conductor-which retards cooling and tends to prevent it from freezing in Winter. The even snow blanket adds a further covering. Under this triple protection the forest soil either does not freeze at all, or freezes to a shallow depth during late Winter. Moreover, it thaws out in the Spring while still under its cover of snow through the evolution of heat produced in the process of fermentation and decay of leaf litter. The slow melting of snow in the forest, together with the unfrozen or slightly frozen condition of the ground beneath, permits a much greater percolation than in the open. 
On account of the forest floor being penetrated by a network of roots and covered by branches, stumps, etc., the surface run off is impeded, permitting the water to sink into the ground. Percolation is further assisted by the presence of deep channels in the soil left by the decay of large roots.

The depth of the soil has a bearing upon the amount of water it can hold. No matter what its characteristics may be, shallow soil cannot retain much water. The forest, however, tends to increase the volume of soil, and thus creates greater reservoirs for water. It does this in two ways. Firstly, from above, by the annual twig and leaf droppings, which, when decayed, become an integral part of the soil, and, secondly, from below, by inducing disintegration of the underlying rock. The forest, by constantly increasing the depth of the soil, lessens the likelihood of its being washed away.

During the growing season, the demand of the forests on soil moisture is intensive. In Summer, the forest, like other crops, consumes more water than it receives in the form of precipitation. At the end of the vegetation season, the level of the underground water is low. As a result, the forest soil can absorb large quantities of water during the period of vegetative rest when there is an excess in the ground, either from heavy rain, or melting snow.

The forest soil, therefore, forms a reservoir whose capacity is greatest when there is an excess of water on the ground and the danger of flood is greatest. The water stored in the time of rest is used by vegetation, and for the flow of streams later on, when there is usually a deficiency of precipitation. This latter feature has a direct bearing on irrigation projects or water supply for town or city use. For, if the soil of watersheds remains soft and unfrozen, the ground water which feeds the streams will continue to flow throughout the winter, thus maintaining a normal winter water stage in the smaller streams that feed the main water works reservoir. If, however, the flow of underground water ceases during winter, the water stage falls, small streams freeze to the bottom, and the ground water accumulates behind the icy dams thus created. In the Spring, not only are the stream basins raised on account of the ice frozen to the bottom, but the ground water that has dammed back at the bottom of slopes bordering the streams, breaks loose and flushes over in large quantities.

For the regimen of rivers and reservoirs, therefore, the importance of forest cover on slopes bordering springs, creeks and small streams which are fed by underground waters is especially great.

\section{FORESTS AND EROSION}

On account of its mitigating effect on stream flow, the ability of the forest to prevent erosion is of far reaching influence. Erosion on cleared slopes above the head waters of streams where agriculture is impracticable, may be pre- 
vented by sodding, by a growth of shrubs, by covering the surface with straw, leaves, and brush, or by engineering processes in the construction of a series of reservoirs to hold the surplus water during flood.

But all of these methods demand a heavy expenditure, and in ordinary cases, are prohibitive. The most permanent, effective, and cheapest protection against erosion is a forest cover, because the resistance to washing is increased by the roots of the trees which hold and bind the soil firmly in place, and at the same time the erosive force of the run off is impeded by the treetrunks and ground litter.

Aside from the havoc wrought to river banks, hill slopes, and ofttimes whole sections of land, erosion has a definite effect on the height of flood waters in the streams, because the sediment carried down by freshets is deposited in the river beds. When the channels become filled with detritus, flooding is the inevitable result even with slight run off which would have little or no perceptible effect, otherwise, upon the height of water in the streams.

\section{Summary of Effects of Forests Upon Stream Flow}

1. The total discharge of large rivers depends upon climate, precipitation, and evaporation. Fluctuation in the total amount of waters carried by rivers during a long period is, of course, dependent upon climate cycles of wet and dry years.

2. Among the factors, such as climate, and soil characteristics which effect the storage capacity of a watershed, and, therefore, the regularity of stream flow, the forest plays an important part especially on impermeable soils.

3. The mean low stages as well as the moderately high stages in rivers depend upon the extent of forest cover, but to a greater or less degree the fact has been proved that forests do tend to equalize the flow throughout the year by making the low stages higher, and the high stages lower.

Without question deforestation has been greater than natural regenera. tion and reforestation together. Lumbering has been increasingly active in Southern Ontario until today instead of the vast forested regions which one time covered our watersheds and protected our river banks, only scattered farm woodlots remain and incipient tree growth along streams and rivers may be likened to that hair restoring ad- "Going, Going, Gone." As a result denudation prevails, a condition that can only be corrected by means of reforestation.

It is a big problem, and a serious one. A few acres reforested cannot be expected to have any material effect on climate conditions, nor induce increased precipitation. Undoubtedly, a small planting on stream banks and hillsides will be instrumental in preventing erosion, locally, but in order to 
establish a district-wide forest influence, public and private participation in reforestation is essential to procure results.

Unfortunately, many streams rise in good agricultural land. In most cases, however, co-operation by the private owner will be of primary importance. If he will realize that by planting his stream banks and bottom lands he is effecting a public service as well as bettering his personal interests by developing wood crops, the problem is well under way of solution. Larger planting projects must necessarily come within the scope of County or Municipal jurisdiction. If land for the establishment of publicly owned forests was chosen with the dual object of developing timber and controlling stream flow, a big step would be made in the right direction.

Although the task may appear herculean, the fact remains that every plantation of forest trees that is set out constitutes an influential factor on stream flow. Reforestation has made marvellous progress during the recent decade, mainly from the viewpoint of growing lumber, and when one considers that this work can be developed along protective lines at the same time, it is not a wild conjecture to foresee in a very few years a rehabilitation of forests on our now denuded river banks and watersheds.

Data procured from a reliable Forest Experimental Station in Europe in dicates the rapidity with which snow melts in the forest, as compared to thawing in open fields. Variation according to species, age, and density of the stand is also signified.

The ground in field and forest became entirely free of snow on the following dates: fields, clearings, and open places, April 22; young, open stands (deciduous) April 24; old open stands (deciduous) April 26; Birch stands, April 29; Pine stands, May 6; Spruce stands, May 15.

Although the above dates of complete snow disappearance are later than normally occur in "Old Ontario," the comparison is at once apparent.

In conclusion I would like to offer suggestions as to what species are best suited for planting steep slopes and gulleys.

The choice of species is, primarily, determined by soil conditions. Certain trees grow better on certain soils. As a general rule, however, conifers should be used where the object is erosion prevention and control of stream flow, because, first, the foliage persists all year, and the protective factor is present when most required during the seasons of climatic extremes; second, loss of soil moisture on account of evaporation is more effectively curtailed due to the dense pine or spruce limb and leaf growth. 
FORESTS AND STREAM-FLOW-NEWMAN

\section{TREES SUITED TO DIFFERENT SOILS}

\author{
Blow Sand \\ Jack Pine \\ Scotch Pine \\ Poplar \\ Willow
}

Deep Rich Loam

White Pine

Scotch Pine

Austrian Pine

White Spruce

Norway Spruce

\author{
Sand and Gravel \\ White Pine \\ Red Pine \\ Scotch Pine \\ Jack Pine
}

Heavy Wet
Scotch Pine
White Spruce
Norway Spruce
White Cedar
Willow

\author{
Sandy Loam \\ White Pine \\ Red Pine \\ Scotch Pine \\ White Spruce \\ Norway Spruce \\ Rocky areas-Thin \\ Red Pine \\ Jack Pine \\ Scotch Pine \\ White Spruce \\ Cedar
}

The foregoing compilation does not take into consideration various in digenous deciduous species, excepting Willow and Poplar, since the object of this writing is to suggest trees that do well on certain soils and are, at the same time, most effective in controlling stream flow and preventing erosion.

It is recommended that deep rooting trees, such as Pines, be used in plant. ing steep river banks and hillsides providing soil characteristics favour a satisfactory development of this species.

Where soil conditions are not suited to pine growth and erosive action is great, the shallow rooting White and Norway Spruce may be used in con. junction with Poplar and Willow. These latter species possess deep rooting propensities, and serve in holding the soil in place until the Spruce becomes established. Willow and Poplar root very rapidly, and lend themselves admirably for immediate action. These species do not, however, enjoy a high status in the lumbering market, thus their use should only be considered as a means to an end.

Other valuable species such as White Ash, Elm and Walnut, all of which develop a deep rooting system, may be used on favourable soils, but should not be planted in an admixture of conifers.

Wherever this method of procedure is possible, its adoption is commended, since both the utilitarian and protective factors are brought into full action.

Considerable space has been given to soil erosion and uncontrolled stream flow as related to the mitigating effect of forest cover. The question, "Why worry about it?", naturally arises, but is answerable by many arguments. The annual loss of agricultural soil on account of erosion and the extent of property damage which is caused by floods, is sufficient answer in itself. These 
may be called tangible reasons, but, there are other insidious influences of denudation traceable to a paucity of forest growth which have a direct bearing on agriculture. Loss of subterranean water as the result of torrential run-off during the period of greatest precipitation results in a shortage of moisture requisite to optimum conditions for crop production. This is especially apparent during a dry cycle. Wells gone dry-so apparent during the past few years-is proof alone that the annual precipitation has been, for the greater part, restricted to the Winter and Spring months and instead of seeping into the soil has been wasted.

Major rivers, such as the Grand and the Thames, supply excellent illustrations of the disastrous results of denudation of their head-waters. These streams reveal a wide variation of seasonal flow. The controlling effect of the forest is practically nil. And, from shallow creeks in the late Summer, they are transformed to dangerous, property damaging, torrential floods, during the Spring break-up.

Reforestation is of practical application in the specific case of stream control in connection with waterworks property. From the standpoint of sanitation, it is essential that all properties bordering springs, small streams and creeks feeding the main reservoir which supplies town or city with water come under the jurisdiction of the civic commission.

Ordinarily, a large acreage of such land lies idle as even cropping or pasturing is liable to cause contamination. It is here that tree planting will not only serve in retaining greater reserve of ground water, but will create a physiological soil condition favcuring a water supply that is clear and pure. 